\begin{tabular}{cc}
\hline International Journal of Engineering \& Technology, $7(4.38)(2018) 912-915$ \\
SPC & Website: ww.sciencepubco.com/index.php/IJET \\
Research paper & International Journal of Engineering \& Technology \\
\hline
\end{tabular}

\title{
The Effect of Company Reputation and Business Strategy on Company Performance of Banking Industry in Indonesia
}

\author{
Tongam Lumban Tobing \\ Faculty of Economic and Business, Padmaja University \\ Bandung, Indonesia \\ *Corresponding author E-mail: tongam.tobing@ojk.go.id
}

\begin{abstract}
The number of offices and assets of go-public banking has increased, but their performance has grown unstable. The condition is allegedly related to the issues of business strategy and company reputation. Hence, this study aims to examine the influence of company reputation and business strategy on banking performance in Indonesia. The research uses quantitative research approach on unit of analysis national banking that has been go-public. So the population in this study is all national banks including government, private, and foreign owned which have been go-public. The process of observation is cross section / one shot, ie in 2017. The primary data is obtained through questionnaire towards 43 go-public banks conducted by a census. Analysis of causality to answer the purpose of research, use Partial Least Square (PLS). The results show that the company's reputation and business strategy significantly affect the performance of banking companies in Indonesia either simultaneously or partially. Partially, business strategy is more dominant in affecting company performance than company reputation.
\end{abstract}

Keywords: Company Reputation; Business Strategy; Company Performance; Banking Industry

\section{Introduction}

In order to improve the access to bank capital, becoming a bank go public can be one solution for banks in expanding access to sources of Third Party Funds. The transparency of go-public bank information increases investment opportunities from investors, thereby expanding access to financial resources through instruments in the capital market. In the period of 2011 s.d 2015 there was an increase in the number of branch offices of go public banks. The number of publicly-owned banks increased from 30 in 2011 to 41 in 2015 . The number of public-owned bank offices also increased $23 \%$ (5,184 offices) from 22,515 offices in 2011 to 27,699 offices by 2015.

In the period of 5 years from 2011 to 2015 , there was an increase of IDR 1.829 trillion total assets of conventional commercial gopublic banks. The total distribution of conventional commercial bank funds had been go-public until December 2011, recorded at IDR 2,633 trillion and increased by $60 \%$ growth in five years, to IDR 4,223 trillion. In terms of profit, within the period of 20112015 there is an unstable profit growth and tend to slow down, although in total in 2015 there was a profit increase of $49 \%$ compared to the total profit in 2011.

The following is a description of conventional commercial bank performance based on Capital Adequacy Ratio (CAR), Return on Assets (ROA), Operating Expenses to Operating Income (BOPO), Loan to Deposits Ratio (LDR), and Non Performing Loan (NPL).

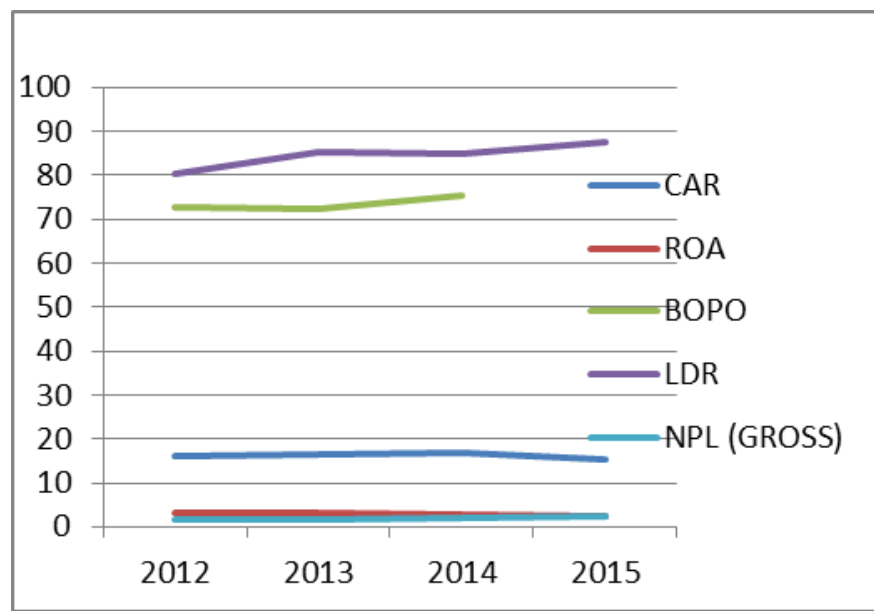

Surce : Financial services Authority, 2016

Fig.1. Growth of the Performance of Conventional Commercial Banks Go Public

Based on the data above, it is known that the performance of banking companies in Indonesia has not achieved high performance. Mean while the concept of performance by [17] is the end result of an activity measured by a company with a number of measures defined in the strategy formulation phase as part of a strategic management process. In performance measurement, [3] uses financial ratios that include Return on Investment (ROI), Return on Equity (ROE), Profit Margin, Market Share, Debt to Equity, Earnings per share, Sales growth, and Assets growth.

Based on observations, preliminary surveys and in-depth interviews with experts in the banking industry, the cause of the unstable performance of banking companies in Indonesia is allegedly 
caused by business strategy problems. [17] explain that business strategy focuses on increasing the competitive position of a product or service from a business unit or company in a particular industry or specific market segment in which they compete.The business strategy in the form of competitive strategy is to compete against all competitors with excellence, and the cooperative strategy is to work together with one or more companies to achieve superiority than its competitors. Based on these opinions, appropriate cooperative strategies and competitive strategies are needed However, the preliminary observations, indicates that banking companies are not yet optimal in applying the right business strategy.

On the other hand, [16] points out through a case study at De Novo Bank that cost efficiency leads to higher profitability. In addition, [14] also found similar results that there was an influence of competitive strategies on performance.

In addition to the problems in the implementation of business strategy, the phenomena are also alleged to be influenced by the phenomenon of company reputation. The company's reputation on service companies according to [18], is directly related to profits (in which the improvements in the company's reputation are related to an increase in perceived profits) and at the same time related to customer sacrifices (in which improvement in corporate reputation is related with reduced costs and sacrifices). Meanwhile, according to [5], there are several key elements in forming a strong and profitable company reputation namely credibility, reliability, trustworthiness, and responsibility. However, from the results of preliminary observations it is known that the reputation of banking companies in Indonesiahas not been high. Meanwhile, [7] show that the company's reputation has a positive effect on the company's performance. In addition, [13] also show a relationship between company reputation and innovative performance.

Based on this background, this study aims to examine the effect of company reputation and business strategy on banking performance in Indonesia.

\section{Literalure Riview}

\section{Company Reputation}

There is a lot of researche on the company's reputation. One of the most famous is Fortune's "World's Most Admired Companies Survey". The criteria used to assess the company's reputation in the survey are: product and service quality, management quality, long-term investment value, attracting human resources, the usage of resources, globalization, financial robustness, creativity and innovation [4]. Reference [4] define the company's reputation as a customer's perception of how well the company is able to safeguard its customers and relate to its welfare. The customer's perception of a company can occur directly through the products and services produced.

Reference [5] argues that there are several key elements in forming a strong and profitable corporate reputation. They include credibility, reliability, trustworthiness, and responsibility.

According to [8], the reputation of service firms is directly related to profits (in which improvement in the company's reputation is related to an increase in perceived profits) and at the same time with regard to customer sacrifices (in which improvement in the reputation of the firm is related to the decline Cost and sacrifice). In this study, the company reputation is measured based on three dimensions namely, credibility, reliability, trustworthiness, and responsibility.

\section{Business Strategy}

According to [9], business strategy is an effort to position the company's business to be more competitive than its competitors. Reference [14] opinion, it is important to evaluate and select a strategy for successful business. Business will succeed if the company has some relative superiority better than its competitors.
There are two sources of competitive advantage found in the business cost structure and the ability to differentiate its business over competitors

Reference [17] explain that business strategy focuses on enhancing the competitive position of a product or service from a business unit or company in a particular industry or specific market segment in which they compete. Business strategy shapes competitive strategy by competing against all competitors with excellence, and / or cooperative strategy by working with one or more companies to achieve excellence over competitors.

Companies can choose five business-level strategies to build and maintain their desired strategic position against their competitors including: cost leadership, differentiation, cost leadership focus, focus of differentiation, and integrated cost leadership or integrated differentiation [8].

In this study, business strategy is measured by the dimensions of competitive strategy and cooperative strategy [17]

\section{Company Performance}

Reference [10] develop performance measurement based on four Balanced Scorecard perspectives: financial perspective, customer perspective, internal business process perspective, and learning and growth perspective. The BSC perspective includes:

a. Financial perspective: measured by account receivable, return on capital employed, operating expense.

b. Customer perspective: measured by customer satisfaction.

c. Internal business process perspective: measured by rework.

d. Learning and growth perspective: measured by employee's morale and employee's suggestion.

Reference [11] measure bank performance by Fixed Assets Turnover, Return on Invest, Return on Equity, Net Profit Margin, Operating Profit Margin, Return on Capital Employed (ROCE),dan Earning per Share. [1] uses Dupont Model to analyze ROE. The ROE model consists of three components: net margin, total asset turnover, and equity multiplier. Reference [6] measure the performance of banking companies through ROA. In this research, company performance is measured by the dimension of growth of public fund, lending growth, profitability level, market share.

\section{Previous Studies}

Reference [7] find that company's reputation has a positive effect on company's performance; [13] find that better human capital moderates the relationship between company reputation and innovative performance. Through a study of 9,276 large US corporations in the 1987-2011 period and reputation ratings from Fortune's "America's Most Admired Companies", it was found that firms with high reputation scores enjoyed lower costs in capital even after controlling for other factors that determine the cost of equity. The reputation rating provides information about the quality of the company. The reputation changes associated with the subsequent changes in the firm's investor base, consistent with reputation ratings that affect investor recognition and increase risk sharing.

Reference [16] points out through a case study at De Novo Bank that cost efficiency leads to higher profitability. In addition, [2] also find similar results about an influence of competitive strategies on performance. [6] examine that in particular, banks pursue cost leadership, differentiation, and focus strategies that are consistent with Porter's typology. Banks with cost leadership have an effect on performance significantly higher than those who are not pursuing generic strategies. Based on the literature study, the hypotheses are arranged as follow:

$\mathrm{H}$ : Company reputation and business strategy affect the performance of banking companies in Indonesia either simultaneously or partially. 
The three variables have not been studied in the unit of go-public banking analysis in Indonesia in 2017.

\section{Research Method}

This study examines the go-public banking in Indonesia using a quantitative research approach. The unit of analysis in this research is national banking that has been go-public. So, the population is all national banks including government, private and foreign owned, which have been go-public. The process of observation is cross section / one shot, meaning that the information obtained is the result of research conducted at a certain time period that is in the year. Primary data is obtained through questionnaire towards 43 go public banks conducted by a census. Analysis of causality to answer the purpose of research uses Partial Least Square (PLS)

\section{Result}

This section will discuss the result of hypothesis testing by using Partial Least Square (PLS). The analysis of structural model (inner model) show the links between latent variables. Inner model is evaluated by using Goodness of Fit Model (GoF), that show the difference between the values of the observations result with the values predicted by the model.

Table 1. Test of Outer and Inner Model

\begin{tabular}{|l|l|l|l|l|}
\hline Variable & $\begin{array}{l}\text { R } \\
\text { Square }\end{array}$ & $\begin{array}{l}\text { Cronbachs } \\
\text { Alpha }\end{array}$ & $\begin{array}{l}\text { Composite } \\
\text { Reliability }\end{array}$ & $\begin{array}{l}\text { Q } \\
\text { square }\end{array}$ \\
\hline Company Reputation & & 0,958 & 0,962 & 0,598 \\
\hline Business Strategy & & 0,878 & 0,908 & 0,578 \\
\hline Performance of Bank & 0,673 & 0,812 & 0,865 & 0,525 \\
\hline
\end{tabular}

Source:SmartPLS 2.0

This test is indicated by the value of $\mathrm{R}$ Square on endogenous constructs and Prediction relevance ( $\mathrm{Q}$ square) or known as StoneGeisser's used to know the capability of prediction with blinfolding procedure. If the value obtained is 0.02 (minor), 0.15 (medium) and 0.35 (large), and only used for the endogenous construct with relective indicator, the value of $\mathrm{R}$ square is amounted to 0.67 (strong), 0.33 (medium) and 0.19 (weak).

The table above gives the value of R2 on the company performance as endogenous variable is in very strong criterion $(>0.6=$ strong), and Q square value is in big criteria, so it can be concluded that the research model is supported by empirical condition or fit model.

The analysis of measurement model (outer model) shows manifest variables (indicators) as with each latent variable. It is used as validity and reliability test to measure latent variabels and indicators in measuring dimension that is constructed. It can be explained by the value of Cronbachs Alpha that is to see the reliability of dimension in measuring variables. If the value of Cronbachs Alpha is bigger than 0.70 [12], it shows that the dimensions and indicators are reliable in measuring variables. The composite reliability and Cronbachs Alpha of variables> 0.70 show that all of variables in the model estimated fulfill the criteria of discriminant validity. Then, it can be concluded that all of the variables have good reliabilities.

The use of Second Order in the research model causes loading factor obtained explain the relationship between latent variablesdimension and dimensions-indicators. The following figure shows the complete path diagram:

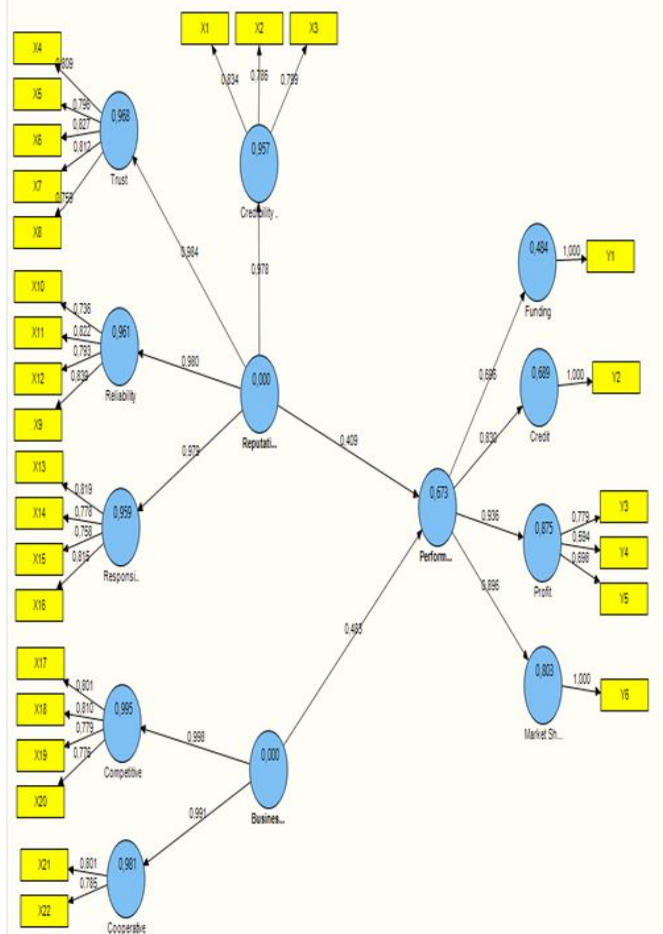

Fig. 2. Complete Path Diagram of Research Model

Based on the research framework, then obtained a structural model as follow:

\section{$Y=0.409 X 1+0.483 X 2+\zeta_{1}$}

Which are:

Y=Performance of Bank

$\mathrm{X} 1=$ Reputation

$\mathrm{X} 2=$ Business Strategy

$\zeta \mathrm{i}=$ Residual

Below is the result of hypothesis testing both simultaneously and partially.

Table 2. Simultaneous Testing of Hypothesis

\begin{tabular}{|c|c|c|c|}
\hline Hypothesis & $\mathrm{R}^{2}$ & $\mathrm{~F}$ & Hypothesis \\
\hline $\begin{array}{c}\text { Company Reputation and Business } \\
\text { Strategy } \rightarrow \text { Performance of Bank }\end{array}$ & 0.673 & $36.51^{*}$ & accepted \\
\hline
\end{tabular}

* Significant at $\alpha=0.05$ ( $\mathrm{F}$ table $=3.31)$

Based on the table, it is known that within the degree of confidence of $95 \%(\alpha=0.05)$ simultaneously there is the influence of company Reputation and Business Strategy on the Performance of Bank amounted to $67.3 \%$, while the rest of $32.7 \%$ is affected by other factors are not examined.

Below is the result of partial testing of hypothesis on the influence of reputation and business strategy on performance partially

Table 3. Partial Testing of Hypothesis

\begin{tabular}{|c|c|c|c|c|}
\hline Hypothesis & $\gamma$ & $\mathrm{t}$ & $\mathrm{R} 2$ & Hypothesis \\
\hline $\begin{array}{c}\text { Company Reputation -> } \\
\text { Performance of Bank }\end{array}$ & 0,409 & $4,900^{*}$ & 0,303 & accepted \\
\hline $\begin{array}{c}\text { Business Strategy -> Per- } \\
\text { formance of Bank }\end{array}$ & 0,483 & $6,280^{*}$ & 0,370 & accepted \\
\hline
\end{tabular}

* Significant at $\alpha=0.05(\mathrm{t}$ table $=2.04)$

The table shows that partially company Reputation and Business Strategy affect significantly to Performance of Bank, in which Business Strategy has a greater influence (37\%). Based on the results of hypothesis testing, the research findings are as follows: 


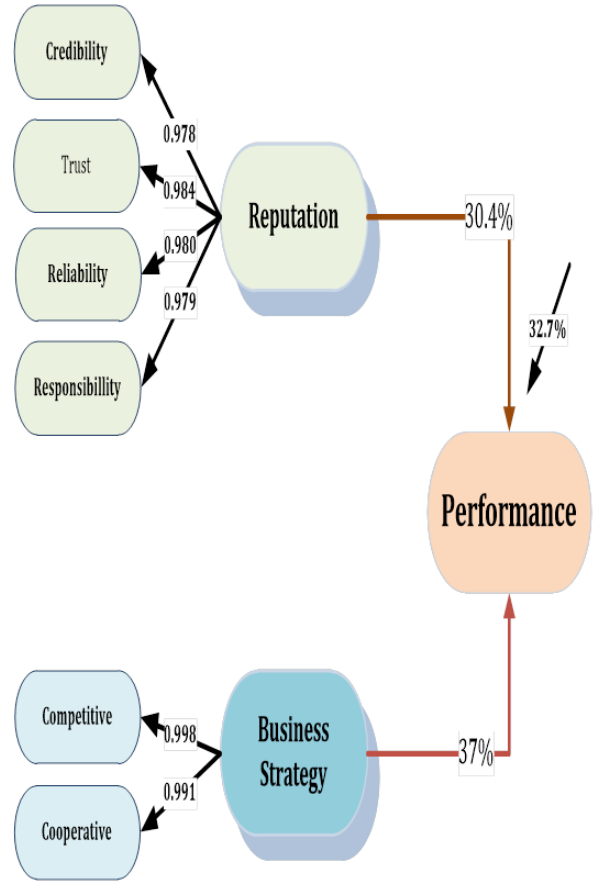

Fig. 3. Research Finding

The finding of this study reveals that company reputation and business strategy have significant effect on the company performance, so this result supports the hypothesis. Business strategy has a more dominant effect than the company reputation in improving the performance of banking companies. Meanwhile, in the development of business strategy, it is revealed that competitive strategy has more dominant influence than cooperative strategy. The reputation development is more dominant formed by trust dimension, followed by dimension of reliability, responsibility, and credibility. So it appears that the improvement of the reputation of banking companies is based on trust development.

These findings indicate that the improvement of banking performance should rely on the improvement of business strategy, especially competitive strategy and supported by cooperative strategy. In addition, the improvement of banking performance should also be accompanied by the company reputation development efforts primarily by increasing stakeholder's trust in banks.

The result of this study indicates the dominance of business strategy in influencing company performance, supporting the findings of [16] which shows that cost efficiency leads to higher profitability; [2] also find similar results that there is an influence of competitive strategies on performance; and [6] who examine that in particular, banks pursue cost leadership, differentiation, and focus strategies that are consistent with Porter's typology. The banks with cost leadership have an effect on performance significantly higher than those which do not pursue generic strategies.

\section{Conclusion}

The results of this study indicate that company reputation and business strategy significantly influence the performance of banking companies in Indonesia either simultaneously or partially. Partially, business strategy is more dominant to affects company performance than company reputation.

The findings of this study can be used as a framework for further researchers who are interested in examining the performance of go-public banking in Indonesia. It can be examined the influence of the company reputation and business strategy on the performance of both public and go public, or syariah bank, whether the level of influence is the same.

In addition, for practitioners, these findings can be a reference in the preparation of corporate strategy to improve banking performance.

\section{References}

[1] Almazari, Ahmed Arif (2012). Financial Performance Analysis of the Jordanian Arab Bank by Using the DuPont System of Financial Analysis, International Journal of Economics and Finance, Vol. 4 no. 4, pp. 86-94.

[2] Banker, Rajiv D.; Mashruwala, Raj; Tripathy, Arindam (2014). Does a differentiation strategy lead to more sustainable financial performance than a cost leadership strategy? Management Decision, Vol. 52 No. 5, pp. 872-896.

[3] David, Fred R. (2013). Strategic Management, Concepts \& Cases. Pearson Education Limited, England.

[4] Duygun, A., Mentes, S. A., \& Kubas, A. (2014). The impacts of complaint satisfaction on corporate reputation: A study on banking sector, International Journal of Trade, Economics and Finance, vol 5 no. 2, pp. 159-160.

[5] Fombrun, Charles J. (2001). Corporate reputation - Its Measurement and Management. Thexiz, 4, 23-26.

[6] Hahn, William \& Powers, Thomas L. (2010). Strategic plan quality, implementation capability, and firm performance, Academy of Strategic Management Journal, Vol.9 No.1, pp. 63-81.

[7] Hasanudin, Agus Ismaya, SE, SH, MSi; Budianto, Roni, SE, Ak, ME. (2013). The Implications of Corporate Social Responsibility and Firm Performance with Reputation as Intervening Variable: Empirical Study in the Manufacturing Company in Indonesia, GSTF Business Review (GBR), Vol. 2 no. 4 , pp.106-109.

[8] Hitt, Michael A.; Ireland, R. Duane; Hoskisson, Robert E. (2015). Strategic Management : Competitiveness \& Globalization: Concepts and Cases, Eleventh Edition, Stamford : Cengage Learning.

[9] Hubbard, Graham, and Paul Beamish (2011). Strategic Management : thingking, analysis, action, Frechs Forest, N.S.W : Pearson Australia .

[10]Kaplan, R.S. and Norton, D.P. (2010). Using the balanced score card as a strategic management.

[11]Karim, Nasir; Ameen, Amjad; Ayaz, Muhammad (2011). Mergers and Acquisitions: An Impact on Financial Performance (A case study of Standard Chartered Bank-Pakistan), Interdisciplinary Journal of Contemporary Research In Business, Vol 3 No. 1, pp.804813.

[12] Nunnally, Bernstein, I.H. (1994). Psychometric Theory, New York : McGraw Hill.

[13] Ou, Yih-Chang; Hsu, Li-Chang (2013). How Does Corporate Reputation Affect Innovative Performance, International Business Research, Vol 6 No.12, pp. 46-59.

[14] Pearce, John A. II, Richard B. Robinson, Jr. (2015). Strategic Management: Planning for Domestic \& Global Competition, International Edition, New York : McGraw Hill.

[15]Rose, P. and Hudgins, S. (2010). Bank Management and Financial Services , 8e, McGraw-Hill/Irwin

[16] Wang, Dan (2007). Three Essasys On Bank Technology, Cost Structure, And Performance, State University Of New York At Binghamton, 171 pages; 3266486.

[17] Wheelen, Thomas L.; Hunger, J. David; Hoffman, Alan N.; Bamford, Charles E. (2015). Strategic Management And Business Policy: Globalization, Innovation, and Sustainability, $14^{\text {th }}$ Edition, Global Edition, Pearson

[18] Zabkar, V., \& Arslanagic-Kalajdzic, M. (2013). The Impact Of Corporate Reputation And Information Sharing On Value Creation For Organizational Customers, South East European Journal of Economics and Business (Online), Vol. 8 No. 2, pp. 42-52. 